\title{
CONTEMPORARy Islamic LAW IN INDONESIA
}

\author{
Sharia and Legal Pluralism
}

\author{
Arskal Salim
}
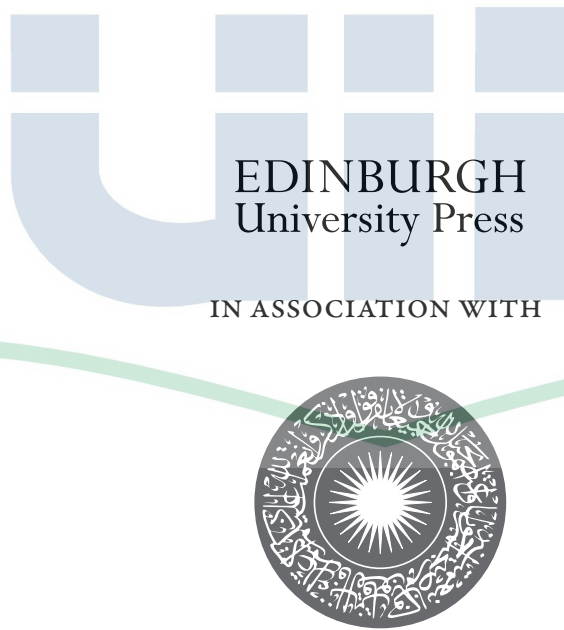

\section{THE AGA KHAN UNIVERSITY}

(International) in the United Kingdom Institute for the Study of Muslim Civilisations 


\section{To my beloved parents Abdul Muin Salim and Arhamy Dappung}

The opinions expressed in this volume are those of the author and do not necessarily reflect those of the Aga Khan University, Institute for the Study of Muslim Civilisations

(C) Arskal Salim, 2015

Edinburgh University Press Ltd

The Tun - Holyrood Road

I2 (2f) Jackson's Entry

Edinburgh EH8 8PJ

www.euppublishing.com

Typeset in $10.5 / 13$ Goudy by

Servis Filmsetting Ltd, Stockport, Cheshire,

and printed and bound in Great Britain by

CPI Group (UK) Ltd, Croydon CRo 4 YY

A CIP record for this book is available from the British Library

ISBN 978 o 748693337 (hardback)

ISBN 978 o 74869348 I (webready PDF)

ISBN 978 I 474403429 (epub)

The right of Arskal Salim to be identified as author of this work has been asserted in accordance with the Copyright, Designs and

Patents Act I988 and the Copyright and Related Rights Regulations 2003 (SI No. 2498). 


\section{Contents}

List of Figures, Diagrams and Table vii Acknowledgements viii Map I: Aceh, Indonesia xii

Map 2: Research sites in Aceh xiii

Introduction

Part One: Between Orders and Jurisdictions

I. Unpacking Legal Pluralism

2. Shifting Legal Orders

3. Competing Jurisdictions

Part Two: Between Justice and Rights

4. Unequal Legal Options

5. Contested Lawmaking

6. Disputed Land Ownership

\section{Part Three: Between Villages and Courtrooms}

7. Orphaned Grandchildren

8. Insurance Benefits

9. Triple Divorce 
Appendix I. The Population of Aceh based on Religious

Affiliation, 2010

Appendix II. The Result of Provincial Legislative Election in Aceh, 2014

Appendix III. Abbreviations and Glossary

Bibliography 198

Index
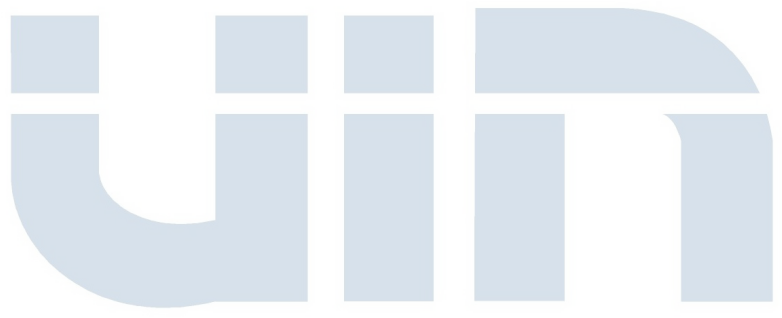


\section{Figures, Diagrams and Table}

\section{FigURES}

2.I Female witnesses are sworn in, in Lhoknga

2.2 An underage orphaned heir and his female guardian are verified by the mobile sharia court

3.I The judges of the civil judiciary examine a dispute

3.2 The Civil Court of Jantho

3.3 The Mahkamah Syar'iyah of Jantho

5.I A billboard banning khalwat as the devil's way to fornication 93

6. I A land document belonging to the defendant Gani $\quad$ I I 3

6.2 The defendant Gani pointing to a blueprint map I I 4

7.I Mediation and legal skills training for village leaders $\quad$ I39

8. I The judges of the Sharia Court in Aceh hear a case of inheritance 157

9. I A handwritten document detailing a decision by village leaders

\section{DiAgRAMS}

I.I Menski's kite model

2.I The sources of law and the hierarchy of regulations in Indonesia 44

7.I Extending the principle of the substitute heir to collateral relatives

TABLE

4.I Regulations on liquor in Aceh and Indonesia 


\section{Acknowledgements}

This is the first of two books that I planned to emerge from my long fieldwork in the post-tsunami Aceh from 2007 to 2008 and frequent visits thereafter. I am greatly indebted to so many people in Aceh who have introduced me to various local (legal) concepts and provided me with information about their life experiences within and beyond courtrooms. Most of them have even been so kind as to offer assistance, guidance and sustenance in one way or another. Without the direction and support I received from many people in Aceh, I would probably have not been able to write this present book.

I would like to first acknowledge Rusjdi Ali Muhammad for his endless support since my first step on Aceh's soil. He has helped me in ways that I cannot forget. He represents a caring father as well as a welcoming host whenever I visit Aceh. He kindly facilitated my first trip and my accommodation when I came to Aceh during the civil emergency status and before the 2004 tsunami. Secondly, I must acknowledge the tremendous support I gladly received from John Bowen of Washington University. Working closely with him over the past five years on various projects, he not only guided me through ways of navigation in the field of legal anthropology, but he also provided me with stimulating ideas for research and publication, including this present book.

The idea for this book in particular stemmed initially from my three-year engagement (November 2006-October 2009) as a postdoctoral fellow at the Max Planck Institute (MPI) for Social Anthropology, Halle, Germany. My special thanks go to this scientific research institution, most notably to the leaders of Legal Pluralism Project Group, the late Professor Franz von BendaBeckmann and Professor Keebet von Benda-Beckmann, who had offered their generous support in many ways. Franz in particular read a few chapters (in their 
preliminary and rough versions) of this book and provided me with written comments. I have benefited enormously from the spirit of collegial exchange that exists among all members of the project group (Bert, Martin, Jutta, Judith, Caroline, Fadjar), who created a stimulating intellectual atmosphere during my three-year stay in Germany. A monthly 'theory evening' at the apartment of Franz and Keebet in Halle, and a yearly retreat to Westensee, six-hour drive from Halle, where Franz's and Keebet's holiday home is located, will always remain in my memory.

While conducting fieldwork in Aceh, a great number of interviewees and colleagues were so helpful and made my work a lot easier. I would like to express my thanks to all my interviewees who serve as judges at the different sharia courts of Aceh for devoting their time and effort to this research. They include Soufyan Saleh, Jufri Ghalib, Rosmawardani, Marluddin, Rafiuddin, Armiya Ibrahim and Zubaedah Hanoum. I also owe special thanks to the professors and academics of the Ar-Raniri State Islamic University of Banda Aceh (Rusjdi Ali Muhammad, Hamid Sarong, Al Yasa Abubakar, Syahrizal, Yusny Saby, Hasbi Amiruddin, Farid Wajdy, Warul Walidin, Badruzzaman Ismail, Safir Widjaya, Ismail Muhammad, Amirul Hadi, Eka Srimulyani, Kamaruzzaman and Aslam Saad), who discussed various socio-religious issues in Aceh with me and provided valuable insight. My thanks also go to colleagues at the Law Faculty of Syiah Kuala University of Banda Aceh (Muzakkir Abubakar, Saleh Syafei, Saifuddin Bantasyam, Taqwaddin, Nurdin Husein) for offering information and analysis on legal political developments in Aceh.

My gratitude also goes to my Acehnese friends at PKPM (Mujiburrahman, Muslim Zainuddin, Hasnul Arifin, Abidin Nurdin, Ridha, Sayuthi, Mahmuddin, Nazir and Khairizzaman) all of whom helped me enormously when living in Aceh (March 2006-August 2006, September 2007-June 2008). My PKPM friends, people at the Aceh Institute (Alkaf, Saiful Akmal, Chairul Fahmi, Teuku Jafar), partners at the ICAIOS (Saiful Mahdi, Reza Nurdin, Rizanna, Sehat Ihsan) and Supriadi Adiguna were so helpful in giving me a sense of being at home whenever I came to Aceh. Many thanks for this friendship throughout the last years.

The research for this book could not have been completed without the financial support provided by different institutions. The MPI for Social Anthropology provided funding for most fieldwork that led to this book. In addition, I am grateful for the British Academy Small Research grant in 2010 that enabled me to investigate a variety of contested norms and practices relating to the aftermath of triple divorce in Aceh. The findings of this research appear as Chapter 9 of this book. I am also thankful for a three-month fellowship offered by the Asia Research Institute at the National University of Singapore that allowed me to revise some chapters and restructure the shape of this book as 
it is now. I was fortunate to receive suggestions from Michael Feener on revising some parts of the earlier draft while staying in Singapore between August and October 20Ir. Likewise, I thank Aga Khan University, Institute for the Study of Muslim Civilisations, London, and Syarif Hidayatullah State Islamic University, Jakarta, Indonesia, for granting me teaching absences over certain periods that I was away on fieldwork research between 2007 and 2010.

I owe much gratitude to all my fieldwork assistants in Aceh (Zarkasyi, Masrijal, Dafiuddin, Ernita, Haura, Reza) and local researchers (Nanda Amalia, Abidin Nurdin, Al Chaidar, Marzi Afriko) who offered information in various ways that helped me to complete the field research. I sincerely thank them for their efforts in various data collection tasks, including arranging visits to meet interviewees, discussing and analysing cases, newspaper clippings, taking pictures of events and transcribing most parts of recorded interviews. Additional support was provided by a number of close friends in different ways. Nadirsyah Hosen has been a great friend. I thank him for not only providing me with enthusiastic conversations during the many virtual or real discussions we have had since we were $\mathrm{PhD}$ students, but also for having shared strategies and tips that greatly helped me stay on an international academic track. Adlin Sila has been a genuine friend who always shares his intellectual fervour and anthropological research with me. I thank him for every endeavour he made to show me what truthful yet academic friendship is.

I feel so fortunate to be part of University of Western Sydney (since late 20I2), and to have received a great deal of support and helpful input on various academic matters, especially from colleagues at the Religion and Society Research Centre (Adam Possamai, Eva Garcia, Julia Howell, Bryan Turner, Jan Ali and Steven Drakeley). Adam has been a great mentor. He not only strongly supports the publication of this book, but he always encourages me to publish more works out of my research.

I am very grateful to various people for helping me in the preparation of this book. My sincere thanks go to Rhubarb Academic Editing, who looked closely at the final manuscript for English style and grammar, correcting both and offering suggestions for clarity and improvement. I also thank Abidin Nurdin and Siska Novirianti, who respectively assisted me by preparing appendices and glossary. A number of editors at the Aga Khan University and Edinburgh University Press (Charlotte Whiting, Farouk Topan, Sikeena Ahmed, Michelle Houston and Nicola Ramsey) have helped me in one way or another in publishing this book. Their professional and careful assistance are gratefully acknowledged.

I feel a deep sense of gratitude to my mother, Arhamy Dappung, and my late father, Abdul Muin Salim, who passed away in May 20 I I. I am dedicating this present book to both of them as a symbol of my love for guiding me in life 
through many of their prayers. Last but not least, I am very deeply grateful to my wife (Maya) and my three children (Akmal, Maykal and Marsal) for the support and loving encouragement they have offered me over the course of my years of work and research. I truly admire the sacrifices they have made to follow behind my steps and to move across countries (Indonesia, Australia, Germany, the United Kingdom and then Australia again) over the past twelve years. Their incredible patience and understanding, for I had to travel to visit research sites, deliver papers at conferences and devote long hours to reading and writing, are far too huge to acknowledge in full. With my most heartfelt thanks, I must say that without them the present book may not have been written.

Finally, Some of the material included in this book was derived from my previous publications as follows:

I. An earlier draft of Chapter 2 appeared in the form of an article: 'Dynamic Legal Pluralism in Indonesia: Contested Plural Legal Orders of Contemporary Aceh', Journal of Legal Pluralism 6r (2010): I-30.

2. Some sections in Chapter 5 have been published in: 'Politics, Criminal Justice and Islamisation in Aceh', Islam, Syari' ah and Governance Background Paper Series (2009), 3, University of Melbourne, Australia.

3. Several paragraphs in Part One of this book were fragments of an article: 'Shari'a from Below in Aceh (1930s-I960s): Islamic Identity and the Right to Self-determination with Comparative Reference to the Moro Islamic Liberation Front (MILF)', Indonesia and Malay World 32 (2004): 80-96.

I thank the editors (Melanie Wiber, Tim Lindsey and Ben Murtagh) of the respective journals and publications for permission to reproduce them in more refined analyses in this book.

Note: In this book specialist non-English terms are italicised at first instance only. 


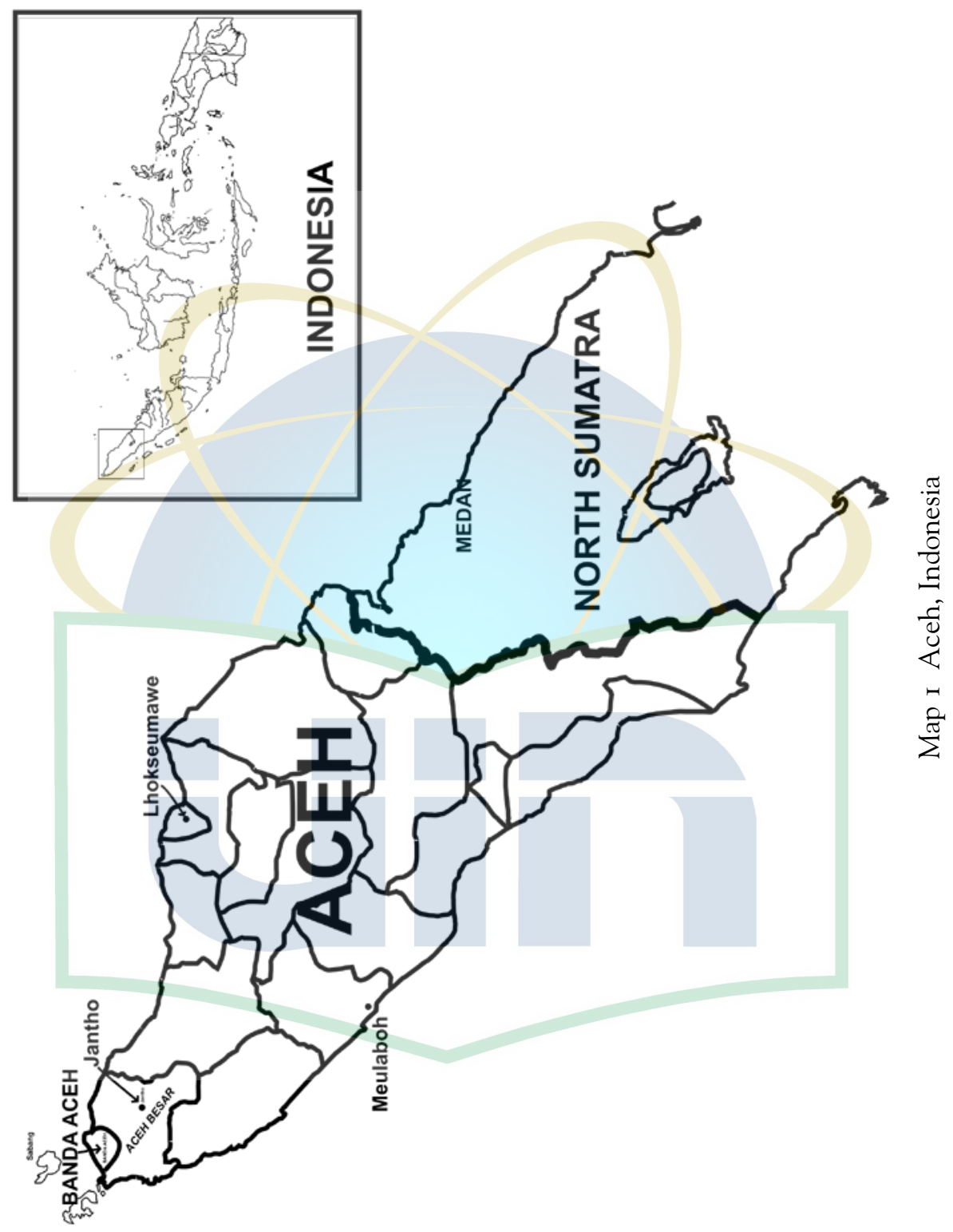




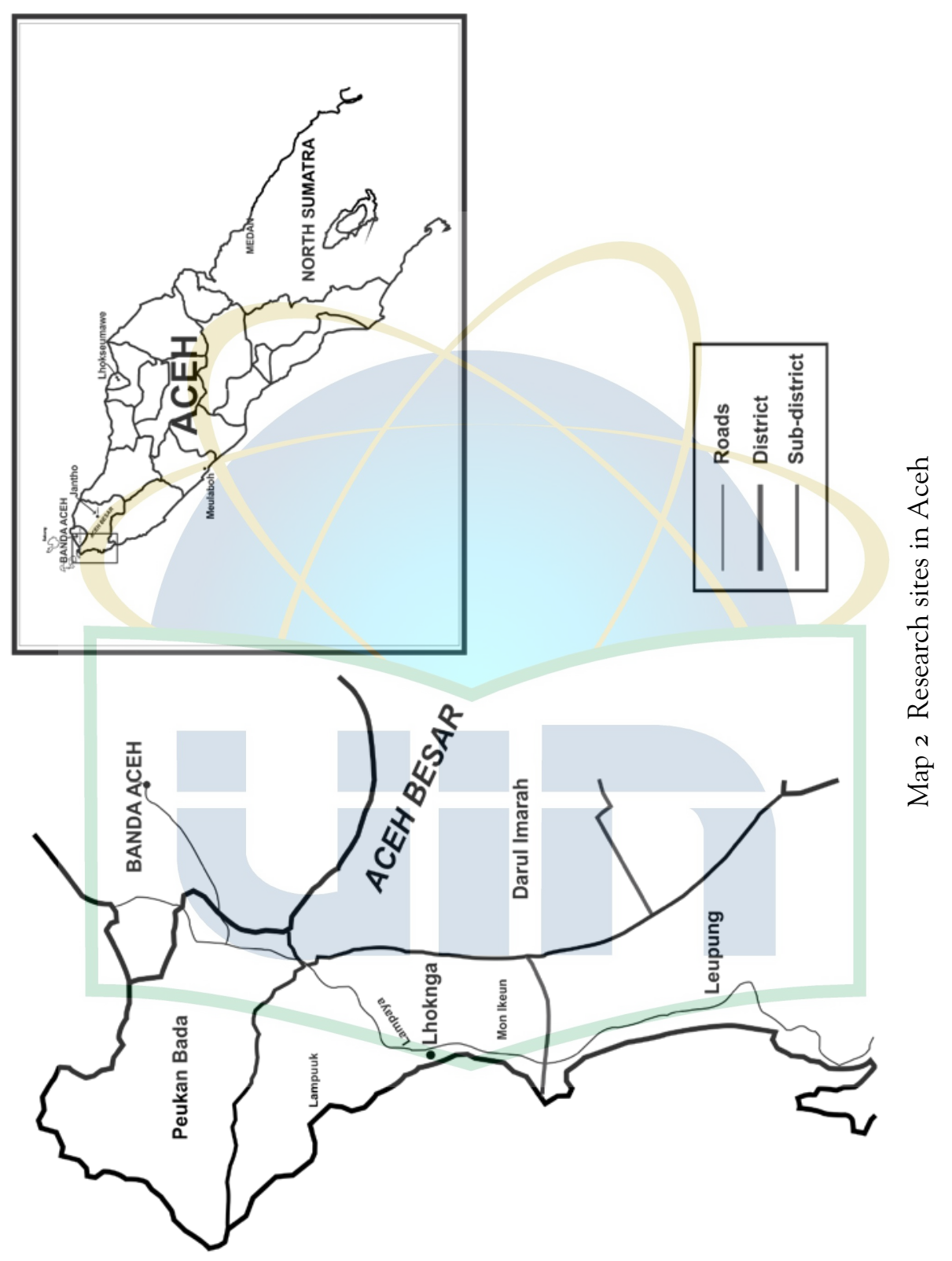




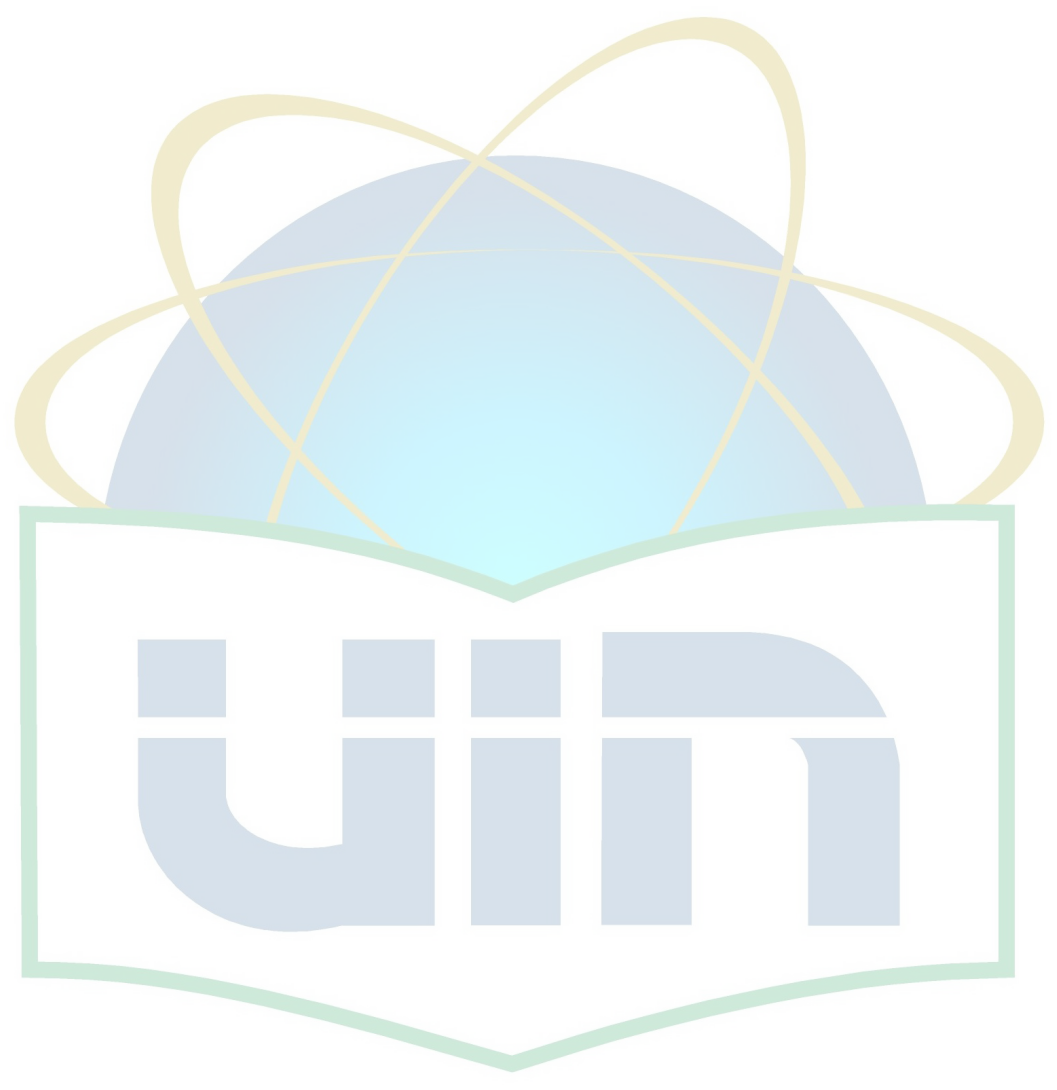




\section{Introduction}

The tsunami and the recovery effort have rearranged the lives and political organization of people,

bringing about changes in cultural practices and settlement patterns, the end of secessionist conflict and a fledging peace process, as well as allowing new political voices and power-based relationships to

emerge.

Grigorovich (2009: I 55)

I went to Aceh, Indonesia, for the first time when I was a PhD student. I was looking at the way in which a programme of Islamisation of the law was being introduced by the government (by incorporating certain aspects of sharia religious law into regional regulations, known locally as qanun) and implemented in this province. For many years, travel to this part of Indonesia, which is located at the northern tip of the island of Sumatra, was restricted. Since 1976, Aceh had been an area of prolonged conflict between the Indonesian military and the Aceh independence movement (GAM). While this had begun with heavy armed fighting and killings in several specific districts, from I 999 onwards there was escalation of the conflict and clashes occurred in almost every district, including the capital of the province, Banda Aceh. ${ }^{1}$

It was late May 2004 when I first stepped on Aceh's soil. The 'military emergency' status in Aceh had ended just a couple of weeks before and had changed to 'civil emergency'. The Garuda Indonesia airplane that flew me from Jakarta landed at noon, and, along with other passengers, I walked into the terminal building. At the entrance doors of the Blang Bintang airport building, I was 
stunned to see so many soldiers standing around with weapons in their hands. They may have just been doing their job, yet, as a native Indonesian originally from a different island (South Sulawesi) and having often travelled to a number of cities in Indonesia without ever encountering this type of situation, I quickly felt that there was something different in and about Aceh and I realised that this province was not comparable to the others. During this first experience of visiting Aceh (for almost a week) I was overwhelmed with anxieties and fears. Five months later, I returned to Aceh during the Ramadan fasting month (October 2004), two months before the Boxing Day tsunami. This time, although I became used to seeing the same scene, I still experienced the same feelings as before.

In June 2005, six months after the devastating earthquake and tsunami disaster, I returned to Aceh. This was not a pre-planned PhD fieldtrip, because all my $\mathrm{PhD}$ research fieldwork had been completed in 2004. My PhD supervisor, Professor Tim Lindsey of Melbourne University, encouraged me to visit Aceh once again to investigate the extent to which the post-tsunami conditions had affected the Islamisation of law in the region. It was a coincidence that at the time of my return to Aceh, the punishment by caning of a number of offenders was about to take place. From the beginning of the process of introducing sharia law, the inclusion of the caning penalty into Aceh's regional regulation has sparked debate among lawyers and jurist scholars in Indonesia, and has attracted severe criticism from the wider international community. Despite this, on 25 June 2005, after the Friday prayer, the first implementation of this punishment - the caning of more than twenty offenders (most of whom were charged with violating the qanun on gambling) - eventually took place in the district of Bireun (four hours' drive from the capital of the province). With the assistance of a local youth organisation based in Banda Aceh, I was able to videotape the first 'Islamic' punishment ${ }^{2}$ officially imposed in a territorial part of the secular republic of Indonesia.

\section{Legal Changes}

The swift and dramatic changes in the legal systems of Indonesia in general, and of Aceh in particular, have taken place in less than ten years. In I999, following the collapse of the authoritarian Suharto regime in May r998, Aceh was awarded autonomous status, with special privileges in some social, legal and cultural spheres. Two years later, the implementation of sharia in Aceh was officially declared and a distinctive court (Mahkamah Syar'iyah) was established to examine offenders against Islamic criminal law. In 2002 and 2003, relevant institutions, rules and punishments were stipulated in regional regulations (known locally as qanun) and passed by the provincial legislature. Although 
legislation on Islamic punishments were introduced in 2002, the legislature did not immediately instigate rigorous implementation of sharia in the region. In October 2002, the chairman of the Aceh ulama council (MPU) declared that Muslims who violated Islamic rules stipulated in the qanun would be lashed. By early 2004, the Syar'iyah Court had sentenced some offenders to the caning penalty. However, up to the time when Aceh was hit by the earthquake and tsunami in December 2004, not a single person had been punished this way. It was only six months after this disaster that the punishment of public caning finally took place.

Was the earthquake and tsunami disaster a crucial factor that made possible and promoted the implementation of the caning penalty? As I have pointed out elsewhere (Salim 2008: I63-4), many people in Aceh considered this calamity a spiritual test or even a punishment from God. In the first months following the disaster, religious sermons delivered on many occasions and at various places centred on this matter. In fact, every evening, at the time of the after-sunset prayer, the Wilayatul Hisbah (religious enforcement officers) marched from one mosque to another to echo and spread this message to the participants in the prayer. It was believed that through this disaster, God had communicated with the Acehnese, advising them to stop committing sinful deeds, to reconcile with each other and comply with sharia rules. It was further understood that the tsunami was God's message to the government to enforce sharia in the province in earnest. ${ }^{3}$

Some people, however, were unconvinced that the tsunami was God's punishment for the Acehnese. To these people, the protracted armed conflicts in Aceh from 1976 onwards, which had caused the deaths of many innocent people, as well as mental and physical wounds, had already been punishment enough. In their view, the large-scale earthquake that led to the disastrous tsunami was merely tectonic activity under the earth, which they regarded as sunnatullah (a natural process). For them, this had nothing to do with whether or not sharia was implemented in Aceh. In fact, the argument continued, as Aceh is located in a geologically unstable area, where earthquakes often occur, there is no guarantee that a future tsunami will not hit Aceh even if sharia were applied fully. For them, the disaster is one thing and the implementation of sharia is another, separate thing, ${ }^{4}$ and, in short, the disaster was not an escalating factor for the implementation of sharia in Aceh. Nevertheless, in my view, it would be hasty to say that the disaster had no significance in the various legal and political transformations in Aceh.

Perhaps the most far-reaching change that the disaster brought about in Aceh was the acceleration of the peace process. On I5 August 2005, eight months after the disaster, through the support of the international mediator, the Crisis Management Initiative (led by Martti Ahtisaari, the former president 
of Finland), both the government of Indonesia and the Free Aceh Movement (GAM) finally signed the Helsinki Agreement and ended the prolonged bloody conflict in the province (Aspinall 2005). Although this complicated peace process had commenced several years earlier, the post-disaster conditions created a particular context in which both parties to the conflict felt the urgency of taking a major step forward and speeding up the peace process (Husain 2007). Given the previous intricate processes involved in this agreement, it was unimaginable that the Helsinki Agreement would have been so promptly signed without such a huge-scale disaster having preceded it.

The Helsinki Agreement served as a legitimate basis for the transformation of the legal political system in Aceh, which led to the issuance of Law I I of 2006 on the Governance of Aceh. This law provides Aceh with a stronger framework that affects changes in the existing legal constellation in Aceh in many ways. This legislation contains explicit provisions on plural legal orders by formally recognising adat (customary) institutions as well as Islamic legal institutions in matters of dispute resolution in their respective jurisdictions. The law has not only reinforced the status of adat institutions ${ }^{5}$ in Aceh, but has also filled gaps and eliminated ambiguities in the previous regulations in relation to the application of sharia in Aceh. ${ }^{6}$ The legitimacy of sharia rules and the status of the Mahkamah Syar'iyah and its jurisdiction have been strengthened and widened. In fact, the 2006 Law on the Governance of Aceh is considered to have elevated the status of the Mahkamah Syar'iyah to a more eminent position. ${ }^{\text {? }}$

This book is an ethnographic account of legal pluralism in Aceh, Indonesia, in what is, simultaneously, a post-conflict and post-disaster situation. A number of significant changes in the legal and political structures of Aceh that have taken place, concurrently, since the demise of the New Order regime, have led to the deepening of legal pluralism in Aceh. Legal pluralism is practically understood here as 'the co-existence of more than one legal order (or mechanism) in the same socio-political field' (F. Benda-Beckmann 2006: 58). While these dynamics of plural legal orders began with the emergence of a new democratic state of Indonesia through the decentralisation policy, it was the post-tsunami recovery processes that accelerated and consolidated the presence of plural legal orders in Aceh.

Some scholars have explained the changes in legal systems that have taken place elsewhere and at other times. A prominent legal anthropologist, June Starr (I992), explained that changes in Ottoman and Turkish law in the nineteenth and twentieth centuries were due to the roles of, and competition between, state elites. Contextualising her field research on law within a theory of cultural, societal and legal change, Starr (1992: xviii) considered both that law is 'a process and that it is shaped by rules and a cultural logic', and 'a discourse fought over by very real agents with different political agendas'. Starr's conclusion was that 
legal changes in modern Turkey were mostly directed by the secular elites who succeeded in the contest, leaving only a few spaces for the traditional Islamic elites who were politically marginalised. Accordingly, the Ottoman Turkish legal system, from the Tanzimat era in the nineteenth century until the I970s, was almost completely secularised.

In the same vein, Franz von Benda-Beckmann and Keebet von BendaBeckmann (2013) discussed political and legal transformation in the relationship between different legal orders in West Sumatra, Indonesia. In their recent book, both writers discussed the transformation of traditional village polity (nagari) from the Dutch colonisation period to the post-Suharto decentralisation programme; namely, from 1999 onwards. In the light of this framework and timeline, the authors analysed changes and continuities within village government through the ever-changing relationship between the three major bodies of law based in state government, religion and adat (custom). Contestation between these different legal realms, especially among their respective supporters (state officials, religious clerics and adat leaders), has helped to (re)shape the existing local structure and legal practice over time.

The above-mentioned anthropological studies conducted by Starr (I992) and $\mathrm{F}$. and $\mathrm{K}$. von Benda-Beckmann (2013) on legal changes were based on a long-term historical perspective. They therefore cannot avoid the prevailing political factors, competition between elites in particular, that (re)shape the final outcome of legal transformation. A shift resulting from political contestation helps to explain why a transformation as well as a reconfiguration occurs in any given legal system. While this book shares this premise, it contends that it is not only competition among elites, but also certain major key events that seem to effect pertinent changes in a legal system. In fact, rapid legal changes cannot be well understood only by looking at a shift in social and political settings, which often takes place gradually. Rather, one has to consider some emerging and inevitable conditions, which are not necessarily political, that have allowed, encouraged and even forced state elites to make rapid changes in norms, institutions and procedures of law.

For this reason, the present book ponders three particular key events that have profoundly affected rapid changes in Indonesia's legal system in general and contemporary Aceh's legal structure in particular: (I) the 2004 Boxing Day tsunami disaster that severely damaged most coastal areas of Aceh; (2) the August 2005 Helsinki Peace Agreement that ended the protracted armed conflict between the Indonesian military and the Free Aceh Movement; and (3) the presence of many international agencies involved in rebuilding Aceh in the post-conflict and post-disaster recovery processes from 2005 onwards. All these key events have ushered in many new initiatives and programmes of rapid legal transformations both at national level and, even more so, at the local level. 
Although the origins of these changes can be traced back to several years before the end of the Suharto regime, the impetus of all this rapid transformation in Aceh was provided by certain key events that ensued following the 2004 Boxing Day earthquake and tsunami.

This book provides a study of probably the fastest changing legal system in the Muslim world. This change has occurred largely because of post-tsunami and post-conflict recovery processes. The post-tsunami rehabilitation process is at the centre of all these transformations, since it not only drove the efforts to end the long-standing Aceh conflict, but also accidentally unlocked Aceh from international isolation with the arrival in the province of numerous global aid agencies. Taken together, the post-tsunami recovery process, the accompanying internationalisation of Aceh, and the development of peace following the Helsinki Agreement have each in their own ways stimulated legal and political transformations that affect the social structure and communities of Aceh. By examining relevant legal knowledge and practice in villages, courts and political spaces, this book demonstrates that the post-conflict and post-disaster recovery processes have hastened changes in legal norms, institutions and procedures.

The book deals with various changes in both the national legal system of Indonesia and the regional legal structure in its province of Aceh. It seeks to complement numerous existing works ${ }^{8}$ on Islam and law in Aceh by offering a legal pluralist perspective. The focus of this book is the encounter between diverse patterns of legal reasoning advocated by multiple actors or put forward by different institutions (be they local, national and international, official and unofficial, or judicial, political and socio-cultural) attendant to a vast array of issues arising in the wake of the December 2004 earthquake and tsunami in Aceh. The book not only studies disputes about rights to land and other forms of property, but it also investigates other types of dispute in a wider sense. It concerns disputes about power relations, conflict of rules, gender relationships, the right to make decisions and prevailing norms. This book presents disputes contested on multiple levels and in diverse forums, either through negotiation or adjudication, and regardless of whether or not they have been settled. These disputes include cases in which various actors from villages, courts, the provincial government and the legislature, the national Supreme Court and even the central state have become closely involved.

\section{WhAT IS LAw?}

This study asks the questions 'what is law?' and 'what does law do?' Moreover, 'what does law do after a natural disaster as a community recovers and rebuilds?'. It not only addresses legal problems and disputes that took place in the 
tsunami-affected areas, but also examines how different actors selectively and interchangeably use particular norms in various cases and forums to secure, or to defend, their interests. The book includes a range of socio-legal issues from the dispute over jurisdiction between (legal) institutions, competing sources of legal rules and the emerging challenges of pre-existing local norms, as well as transnational legal issues. For this venture, I would like to consider three main approaches in legal anthropology, as described below.

\section{Law as Culture}

The 'law as culture' thesis initially emerged from the debate between Gluckman (1955) and Bohannan (1957) on the issue of whether or not the legal logic and the process of reasoning in dispute settlements are present in all societies in the same way. The work of Clifford Geertz ( 1983 ) shed light on this debate. Geertz considered that norm or value should be called 'law' if rooted in the collective resources of culture rather than in the separate capacities of individuals. This was because, for Geertz (1983: 215), 'law is local knowledge'. Geertz (1983: $2 \mathrm{I} 8,232)$ thus argued that law is 'a species of social imagination', in which it 'is constructive of social life, not reflective, or anyway not just reflective, of it', and, hence, different cultural traditions maintain different legal sensibilities. Lawrence Rosen, who studied an Islamic village court in Morocco, echoed Geertz's conception of law as an expression of culture. In one of his books, Rosen (2006) argues that law is actually part of culture's way of expressing its sense of the order of things. Rosen (2006: 7) suggested that law must not be seen simply as a mechanism for attending to disputes or enforcing decisions, not solely as articulated rules or as evidence of differential power, but as a framework for ordered relationships. Law, in Rosen's understanding, cannot be detached from an orderliness that is itself dependent on its attachment to all the other realms of its adherents' lives.

The theory of law as culture, especially in the sense of Rosen's legal definition, is characterised as ordered relations. This is quite problematic in the sense that it is more often than not that law produces inequalities as well as discrimination among members of a community. This approach to law tends to fail largely because it often ignores not only the diversity within one specific culture, but also political and economic contexts in which norms are invoked, challenged and restated. What is more, the cultural system does not always work to influence subjects' legal actions. Instead, what become the main factors that drive people's legal movements, as pointed out by Starr and Collier (I989), are asymmetrical relationships between different (legal) orders and differences among people's access to resources. 


\section{Law as Domination}

Sally F. Moore (2005) noted that 'law as domination' has been one of a number of popular approaches employed by legal anthropologists. What is central in this approach is the 'elite interest' argument, where law is purported to serve the cause of the more politically powerful parties. A part of this theory is 'law as a tool for social engineering'. As a result, instead of the norm, it is power that determines the outcome (Gulliver 1963, 1969). The 'law as domination' theory is problematic for two reasons. The first, as pointed out by Lazarus-Black and Hirsch (1994), is that this line of argument does not adequately consider that law is both the vehicle for material domination and cultural reproduction, and the site for local opposition to that domination and the struggle over cultural meaning. Thus, law not only consolidates and legitimates power positions, but it also serves as a resource for less powerful individuals or population groups in their struggle against domination as well as exploitation (F. and K. BendaBeckmann 200I). The second reason is that the 'law as domination' thesis does not adequately take the disputing processes into account. It lacks the notion that disputing is, as Merry (I990: 5) put it, 'a process of meaning making, or, more precisely, a contest over meanings'. The process of dispute is not only an arena for securing justification for the claimed interests, but also a site for meaningful construction that can be mobilised to contest for domination as well as against subordination.

\section{Law as Contested Field}

June Starr and Jane F. Collier (1989) observed that there has been a shift in the main concern of the anthropology of law, from seeing a dispute as something to be resolved at the local level towards seeing local disputes as embedded in larger, often dialectic, conflicts between different interests. In light of this, the framework preference of this book is centred on the interests of different actors in the disputing processes. My study is particularly interested in seeing law as a means, in a great variety of ways, by which people, groups or the state act in their own interests. In this case, 'law offers a legitimate frame of reference in which political, economic and legal interests are defended' (K. von Benda-Beckmann 200Ib: 44). Thus, this book considers law as a contested field, in which, as pointed out by F. von Benda-Beckmann (2002) and K. von Benda-Beckmann (200ra), not only may different legal norms exist parallel to and in competition with each other, but also various legal orders may challenge one another, often with none being self-evidently superior to the others.

My objective in this study is to explain law as a contested field; I agree with both Starr and Collier (1989), who conceptualise law as embedded in, and 
created by, particular historical circumstances and by interrelationships between local, national and international elements. This book therefore examines legal changes in contemporary Indonesia, in Aceh in particular, by addressing local meaning and also history and power (Starr and Collier 1989). It not only discusses legal changes, political contestation or village disputes as something to be resolved locally, but it also considers, most importantly, all those legal and political transformations as embedded in larger, often dialectic, conflicts between different actors, interests and values. Law thus becomes a showground where not only may separate legal orders compete or co-exist, but where numerous, yet different, legal subjects and norms may also challenge one another. This book is, therefore, not mainly the ethnography of Acehnese society, rather, it is the ethnography of legal disputes, practice and institutions. Its central concerns are the relations of individual actors to various legal forums and traditions as seen from outside formal legal institutions.

\section{Background and Islamic Context of Aceh}

By the end of 2012 , Indonesia had thirty-four provinces. Earlier, during the late New Order period, Indonesia had twenty-seven provinces, including East Timor. After East Timor became an independent state in 1999, Indonesia acquired some new provinces by way of splitting up those provinces that had large land areas or big populations. The eight new provinces of the post-New Order are North Molucca (1999), Banten (2000), Bangka Belitung (2000), Gorontalo (2000), West Papua (2001), Riau Island (2002), West Sulawesi (2004) and North Kalimantan (2012). Of the thirty-four provinces of Indonesia, five have special status in that they are allowed to make some governmental arrangements in particular aspects of government. These provinces include Aceh, Jakarta, Yogyakarta, Papua and West Papua. However, Aceh is the only province granted special autonomy in the implementation of sharia.

Aceh is located at the northern tip of Sumatra. Following the decentralisation policy in the aftermath of the centralised Suharto regime, there are now five municipalities and eighteen regencies in this province. Banda Aceh is its capital. Along with a provincial legislature, a governor, with his lower administrative staff (mayors and heads of districts), holds full responsibility for governing the province. Unlike the Dinas Syariat Islam (Islamic Sharia Department) that constitutes the provincial government structure, the police, military, public prosecutor and courts (both civil and religious) of this province are all branches of, and subordinate to, their central government offices in Jakarta. These branches are not only available at the provincial level, but also exist at the district regional level. In fact, as in other places in Indonesia, the police station is present in each of the sub-district areas in Aceh. 
According to the 20 Io census, the population of Aceh was about 4.5 million people. The previous census, in 2000 , was not properly conducted due to security issues. It was estimated, however, that Aceh then had more than 4 million people. So, within ten years, there had been an increase of more than io per cent. There was little accurate information as to how many people were in Aceh before and after the December 2004 tsunami disaster. Nevertheless, the Central Agency on Statistics (BPS) of Aceh issued an estimate that in 2003 the population of Aceh was 4,2 I 8,500. This figure decreased to 4,075,500 in 2004, and decreased even further in 2005 to 4,03 I,600. In 2006, the population increased to $4,153,600 .{ }^{9}$ No detailed explanation was offered as to why the size of the population of Aceh had changed in this way over this period of time. Many are sure, however, that the fluctuation had to do with the devastating catastrophe and the ensuing recovery processes.

As far as socio-political categorisation in the pre-modern history of Aceh is concerned, there were at least four distinct groups: (I) the uleebalang (aristocrats), who were self-governing rulers and controlled most of the trade (including that with the Dutch) and collected taxes in their respective authorities; (2) the sultan, who tried to restrict the uleebalang's autonomy and competed with them to control trade internally and externally; (3) the ulama (religious leaders/ scholars), who were isolated at Islamic dayah (learning institutions) and led the struggle against the Dutch who befriended the uleebalang; and (4) ordinary people, such as peasants or small landowners, who comprised the majority of Acehnese (Schröter 20I0).

In the twentieth century this categorisation totally changed. The first two groups were gone by the middle of the twentieth century: the Dutch abolished the sultanate of Aceh in the first decade of the twentieth century; and the ulama attacked and killed many uleebalang figures in the 1948 Cumbok massacre (Syamsuddin 1985). A new social group emerged during the New Order period ( I966-98), namely, the technocrats. This group was a combination of academics, military officers and bureaucrats in the regional government. In the view of Morris (1983), the technocrat was regarded as a 'new uleebalang', who worked cooperatively with the New Order government.

In the aftermath of the New Oder period, especially after the 2005 Helsinki Peace Agreement, the social composition within Acehnese society changed once again. This change was triggered by the recent emergence of former elites and members of the Free Aceh Movement (GAM) into the political arena as a result of occupying important bureaucratic positions in Aceh's provincial government and gaining a majority of seats at the local legislature (Stange and Patock 20Io; Ansori 2012). In fact, some of them have been involved in major development projects in the province and have become (un)official business counterparts of the government (Aspinall 2009b). This new development has 
not only reconfigured the social composition of the Acehnese, but it has also created a need to redefine who are the uleebalang and which group aptly represents them in the contemporary context of Aceh.

Given that Islam came to Indonesia for the first time through Aceh, ${ }^{10}$ the Acehnese are proud of having accepted Islam earlier than other Muslim ethnic groups in Sumatra or the other islands of Indonesia. Muslims are the majority population in Aceh. According to the 2010 census, they make up 98.8I per cent of the total population of this province. The rest of the population (I.I9 per cent) is a mix of other religions, such as Christians, Buddhists, Catholics, Hindus and Confucians (see Appendix r). As pointed out by Schröter (2010), while the Acehnese are widely considered the staunchest Muslim adherents among Muslim ethnic groups in Indonesia, the population is far from homogeneous. Instead, they are not only culturally and ethnically diverse, but also their religious practice is fundamentally plural (Bowen 1993, 2003).

Islam and politics in modern Aceh have been characterised by the competing roles of, and the contested power between, the ulama, on the one hand, and other political entities, on the other. For many decades, the ulama sought to actively mobilise the expression of Islamic identity in this region and to influence its society by a number of means. ${ }^{11}$ In the first years after Indonesia's independence, they were able to control the local government in Aceh. Nonetheless, they encountered some difficulties in reconciling the Acehnese Islamic identity with Indonesia's religiously neutral ideology, Pancasila. The organisation of the Acehnese ulama (Persatuan Ulama Seluruh Aceh - PUSA), under the leadership of Teungku Daud Beureu-eh, eventually declared the secession of Aceh from Indonesia in 1953, and became part of the Negara Islam Indonesia (Islamic State of Indonesia) led by Sekarmadji Maridjan Kartosuwiryo in West Java (van Dijk I98I; Syamsuddin 1985). However, as this revolt was brought to a stop in the early i 960 , the power of the ulama declined across the whole province.

Forming an alliance with the Indonesian military, the ulama of Aceh had another chance to return to the local political arena following the banning of the Indonesian Communist Party and the downfall of President Sukarno in the mid-I96os. Working closely together during this political transition, the ulama received the green light from the military to reorganise themselves under a new organisation of ulama (Majelis Permusyawaratan Ulama-MPU). In spite of this, there was a suspicion that the new organisation of ulama would resemble the earlier rebellious PUSA. For this reason, the military directed the organisation to carry out its programmes generally to maintain local security and political stability rather than enhancing religious awareness among Muslims. The resulting coalition between the ulama and the military was thus superficial and, in fact, proved to be the first step in a process by which many ulama were co-opted by the incoming military-backed government (Salim 2008: 144-6). 
During the more than three decades of the New Order (I966-98), the ulama were provided with a respectable status and generous incomes by the government. They were not only offered positions in the ulama organisation, but also positions as judges in the religious courts, as lecturers and professors at the State Institute for Islamic Studies (IAIN Ar-Raniry), as teachers in the state or private Islamic madrasa (schools) or as chiefs of the offices of religious affairs in each city and regency in Aceh. Only a few ulama (who lived in rural areas in particular) could escape this political co-optation. These ulama devoted their energies to religious education in their respective dayah, thus allowing them to maintain moral authority and integrity among the people of Aceh (Salim 2008: I 49-50). As they were isolated from many of the government's development programmes, on legal development in particular, the legal views of the rural ulama remained conservative and for numerous cases they preferred to apply only traditional Shafi'i jurisprudence. By ignoring most of the Islamic injunctions that had been incorporated into some national legislation, they sought to portray themselves as the guardians of an authentic identity of Islam in Aceh.

In the post-New Order era (from 1998 onwards), the ulama were once again offered a key political role. This offer was not intended solely to provide the ulama with a greater role thanks to two national laws (Law 44 of 1999 and Law I 8 of 200I) that granted Aceh special autonomy to apply sharia comprehensively. Instead, the offer was mainly directed towards helping to restore the declining position of the technocrats' leadership in Aceh following gross human rights violations and economic exploitation in Aceh during the New Order period. By way of bringing the ulama and the technocrats to work jointly for the implementation of sharia in Aceh, it was expected that the technocrats' political legitimacy would be strengthened and therefore able to counter the increasing popularity of the separatist movements and other opposition groups in Aceh (Salim 2008: 152-3). This ultimate objective, however, was not achievable.

The role of the ulama in the post-tsunami and post-conflict recovery processes remains marginal. The power they acquired based on a series of national laws has been mainly symbolic or rhetorical in the current political atmosphere in Aceh. Their influence upon a variety of policy-making processes in the post-tsunami situation remains relatively weak. The way they engaged in formulating the blueprint for the rebuilding and reconstruction of Aceh demonstrated their weaknesses. Although the MPU had officially requested that the government listen to its voice, the contribution by the ulama to the blueprint formulation was not favourably considered. For this reason, they were mostly unhappy with the blueprint. The ulama, who mostly came from rural areas, organised a meeting to criticise the blueprint as lacking sufficient religiosity. At this meeting, they once again insisted that the government must engage in 
consultation with them in forming any policy to redevelop Aceh. National or international aid agencies seeking to support the redevelopment of Aceh should also consult them. These demands by the ulama, however, have not had much impact (Salim 2008: r66).

\section{Sources ANd Approaches}

After fieldtrips to Aceh for my $\mathrm{PhD}$ research in 2004 and 2005, I had an opportunity to return to Aceh in 2006 and stay quite a lot longer. From March to September 2006, I was hired by the International Development Law Organisation (IDLO) to produce legal documentation compiling legal principles and processes relating to land, guardianship and inheritance, with particular reference to women's involvement (Salim 2006). For this, I made observations and interviewed village elders of the tsunami-affected villages located in Banda Aceh and Aceh Besar. I also met with judges of sharia courts in both areas and discussed relevant legal issues with them. From the legal documentation a number of law manuals and a legal documentary film were then generated, which have been useful as legal resources and as an information service to assist (female) tsunami survivors in claiming (back) their rights in the aftermath of the disaster. For six months living in Aceh, I not only studied a vast array of local knowledge, customary principles and institutions, but also extended my networking and interaction with numerous important local figures from academia, the judiciary, the bureaucracy, civil society and international aid organisations.

As part of my postdoctoral research fellowship, funded by the MPI for Social Anthropology, I conducted lengthy fieldwork and lived, from August 2007 to May 2008, in a village of Lhoknga sub-district, Aceh Besar. This village is not far (about $18 \mathrm{~km}$ ) from the capital of the province, Banda Aceh. However, it is much farther from the capital of Aceh Besar district, Jantho, where both the district sharia and civil courts are located. It was almost $50 \mathrm{~km}$ and there was no regular or direct public transport from Lhoknga sub-district to Jantho city. Many ideas and much of the material for this book derived from my ten months of fieldwork in Aceh Besar district. The last four chapters, in fact, comprise case studies that mostly took place in this region.

Through daily interaction with people in the village and its neighbouring communities, I was able to comprehend why and how legal pluralism has been at the heart of the Acehnese understanding. For many Acehnese, Islam and local custom are not different entities. There is a widely shared proverb among the Acehnese: agama ngon adat han jeut cre, lagee zat ngon sifeut (religion and adat cannot be separated, both are like the substance of something and its attribute). Various practices within the local community are therefore considered naturally religious as well as customary. 
For the first half of my stay in Aceh, I looked at how religion was employed by people who became involved in disputes. It was not easy to detect whether each of the contending parties invoked religious ideas, norms or motivations in their claims as well as argumentations. What often appeared on the surface in many disputes was economic, financial or social and political interest. For this reason, I decided not to investigate the basis of the claim or legal reasoning in order to locate the role of religion in the disputation processes. Rather, I looked at a concept that leads to ending a dispute - musyawarah mufakat, a traditional mechanism of mutual consultation to reach consensus or agreement among contending parties with the help of elders or third parties. This is the way many Acehnese seek to make sense of their social world. For the Acehnese, peaceful consultation is one of their fundamental principles, in which the unity of both adat and religion can be secured. This unity does not become a primary reference only in community life, but also reflects the critical role of religion in dispute-management processes in Aceh.

In connection with the unity of religion and adat in Acehnese society, a very popular Acehnese aphorism (hadih maja) is worth mentioning here: meunyoe buet ka mupakat, lampôh jirat jeut ta peugala (if a consensus is to be achieved, even the cemetery park can be pawned). This aphorism maintains that for the purpose of achieving social agreement, the Acehnese would even compromise sacred property. Some outsiders may observe that the Acehnese do like to have disagreements or tensions in their practical interaction with one another. Yet it must be borne in mind that the Acehnese are always very fond of ending conflicts and achieving a consensus. For them, a peaceful settlement through any means is the key to terminating every kind of dispute. Nevertheless, not every dispute can end peacefully. In fact, a failure of mutual consultation takes place when either of the contending parties senses injustice or experiences oppression. The principle of the unity of religion and adat thus collapses.

While living and studying in the village during my long stay in Aceh, I paid numerous visits, on a regular basis, to civil and sharia courts in both Banda Aceh and Jantho. At the courts, I looked at legal dossiers and archives of decisions. These are good sources for finding summaries of court cases and include a variety of information. Although these sources alone cannot be taken to reflect actual social practices, they help to illustrate what has happened between parties contracting a marriage, seeking grounds for divorce, establishing claims of rights to particular properties, and presenting evidence and legal reasoning before the judges. They also show the considerations of the judges and their final decisions. In short, the summaries of court cases do attract further analysis and discussion on contested claims, competing norms or conflicting rules.

To accomplish the archival study of court cases, I also had discussions with relevant people, including chiefs of court, judges, clerks, both parties to litigations 
and their respective lawyers. With the permission of the participants, many of these interviews were taped. The interviews normally took between half an hour and two hours, depending on the time available to the interviewee. Some people were interviewed more than once to ensure their views had been accurately recorded. The interviews focused on a range of aspects, such as knowledge about a case in question, claims made by both contending parties, evidence brought before the judges, legal reasoning put forward to support claims, and views on, and positions regarding, the particular case. By comparing and contrasting data resulting from different interviews and investigative processes, I was able not only to better understand the part or role played by each individual actor in a case in question, but I could also cross-check each source of information against others to identify whether there were incorrect or one-sided accounts.

On some occasions, I was invited to sit with the Higher Sharia Court's judges in Banda Aceh and listen to their discussion on certain appealed cases that they were examining. Hearings and evidence presentation were no longer necessary at this level of adjudication. The judges were evaluating the decision issued by the lower courts and assessing whether legal substance, or its procedure, had been upheld correctly and consistently. At the first instance level, the composition of judges comprises a panel with one chair and two members. The panel at the appellate level, likewise, has three judges. The court's unanimous decision is, therefore, not always guaranteed. Some judges were keen to apply the black-letter law in a given issue. Yet there were others who sought to go beyond the legal text and make a reinterpretation in the light of analysis of gender issues or socio-cultural changes.

One of the cases discussed by the judges at such a meeting was a dispute over an inherited land parcel, involving a daughter who had lost both her parents in the tsunami disaster while a sibling of her father's still survived. Basing its decision on the Compilation of Islamic law (KHI Article I 76) as well as the general practice in many places in Aceh, the lower court had decided to give a half share to the daughter. When the case reached the Higher Sharia Court, the appellate judges were in disagreement. One of them concurred with the lower court's decision. However, the other two judges were against the decision and instead viewed the daughter as the sole heir, who would therefore be entitled to receive all the land. According to a senior judge, the decision to allocate all the inheritance estate to the only surviving daughter has become a yurisprudensi tetap (consolidated jurisprudence), which means an established decision that is repeatedly applied by the Supreme Court to similar cases that they examine. ${ }^{12}$

The jurisprudence of the Supreme Court on inheritance disputes has been important for two reasons in particular. First, no single provincial qanun (regulation) exists to deal exclusively with Islamic inheritance law. Secondly, the 
Compilation of Islamic Law (a legal handbook that includes inheritance issues and is to be used by Indonesian religious courts) is a non-imperative guide. Despite the fact that Indonesia is not a purely common law country (in fact, it is a country with a civil law tradition), the jurisprudence on inheritance cases becomes crucial, since it acts as a precedent, dictating that all judges acknowledge it as a valid and superior reference. Failure to comply with this convention will have no formal sanction, but judges who do not comply will be considered less capable of correct adjudication.

Many studies ${ }^{13}$ on the ways in which judges in Islamic courts make their decisions have inspired the approach of this book. Some of those works paid particular attention to gender equality in the courtrooms, while others focused on contending argumentation between different norms in the disputes examined in the religious courts. Following their approach, I have studied plural legal reasoning inside and outside courtrooms, not only by investigating conflict or disagreement about claims to rights to various forms of assets, but also by analysing gender relationships and, more importantly, contested norms in the disputing processes.

As this study considers law as a contested field, it looks at what kind of norm is applied or adhered to (that is, figh (Islamic jurisprudence), adat principles, provincial regulations or qanun, national legislation and international norms), and how much it has been taken into account by the various individual actors (be they rural villagers, tsunami survivors, landowners, heirs, local religious leaders, officials or politicians and judges) in making their claims and justifying their arguments in the dispute processes, over a range of legal issues in the post-conflict and post-disaster period. This study is particularly interested in analysing disputes and how various actors, directly or through their institutions (village meeting, sub-district religious office, civil or sharia court, the national Supreme Court, the provincial government and the central state), refer to and use, selectively and interchangeably, particular norms in various cases and different forums to secure, or to defend, their rights, as well as to uphold justice and restore order. Relationships among these actors, or their institutions, have never been monolithic. They are often characterised by internal contradiction and external conflict. Actors, or their institutions, may independently co-exist, either within or outside a particular hierarchy level. Their stances, aims and jurisdictions may overlap or be in competition. Actors and institutions may not only work together to strengthen, or to give a higher priority to, a particular norm, but they may also attempt, either jointly or separately, to exclude a single norm or provision for a shared aim or for their own particular purpose. Given this intricate constellation, it is hard to imagine that there would be a single unitary dominant rule or norm that prevails at all times and in all places. 


\section{An Overview of the Book}

This book uses case studies to examine plural legal constellations of customary rules, religious norms, state laws and international conventions formed as a result of historical circumstance and conflict between the legal reasoning of different actors in disputes. In addition, it will focus not only on individuals and groups who use laws and legal processes to pursue their own ends, but will also pay attention to local and national socio-political processes, international dimensions that (in)directly affect local people, issues and norms that affect legal subjects as representative of particular socio-economic interests, and principles that represent different ideological positions. The discussion therefore includes a range of socio-legal issues, from the dispute of jurisdictions between (legal) institutions, competing sources of legal rules and the emerging challenges of pre-existing local norms, to transnational issues.

This book has three parts. Part One looks at the changes in the legal system that have taken place over more than a decade in Aceh, during which a special autonomous status was formally granted enabling Aceh to implement sharia. Considering a number of factors that caused changes, such as the collapse of the New Order regime in 1998, the 2004 tsunami tragedy and the 2005 Helsinki Agreement, this part discusses how such changes have affected existing legal orders and made shifts in jurisdictions. After the notion of legal pluralism is unpacked in Chapter I, to show how this book employs it as an analytical tool, Chapter 2 presents a case showing the increasing jurisdiction of Aceh's sharia courts, on the one hand, and the declining authority of civil courts in present-day Aceh, on the other. The chapter seeks to offer an explanation of how a shift, as well as contestation, was taking place in the plural legal orders of Aceh. By presenting this case, the chapter not only shows that elements in plural legal orders actively interact and even contest one another, but it also unveils a shift in legal pluralism through its description of distinct social fields that have different sources of content and legitimacy for the plural legal orders that belong to a single legal system. The various changes in the legal status and designation of sharia courts in Aceh demonstrate one of the tensions between legal centralism and legal pluralism in the country's history.

Chapter 3 elaborates and clarifies the extent to which the jurisdiction of Aceh's sharia courts has expanded in a real sense. This chapter demonstrates that the state's offer of increasing jurisdiction to the sharia courts did not practically translate into widely broadened scope and strengthened authority. In fact, the ambiguity, as well as the contestation, resulting from the condition of plural legal orders was observable in a number of ways. This chapter presents several cases to demonstrate overlapping or competing jurisdictions between different state legal institutions in Aceh (civil and sharia courts). As proved through a 
number of property ownership disputes brought before different courts in Aceh from the early i 980 s until as recently as 2012 , the extent to which Aceh's sharia court is able to exercise broader jurisdiction remains mostly on paper. In fact, the civil courts have clearly resisted the expanding jurisdiction of sharia courts.

Part Two presents implications of legal transformation that resulted in asymmetric legal pluralism, modified processes of local legislation and enhanced understanding of rights among different actors. Chapter 4 highlights a salient feature of the unequal legal options available for Muslim litigants. The 2006 law on the governance of Aceh has reinforced this legal configuration. This law enforces the principle of personality, rather than the territorial principle, implying that the state has created a legal distinction between its citizens based on their religion. A sub-section in this law provides non-Muslims citizens with legal choices in some penal offences (such as alcohol consumption and gambling). Instead of going to the civil court, non-Muslim offenders are allowed to opt for adjudication and sentencing by the sharia court. The choice of court is not available to Muslim offenders. Although legal pluralism has been a key feature in Islamic legal thought and practice, Muslims in Aceh do not have the right to move across different legal orders and jurisdictions.

Chapter 5 focuses on the struggle between different groups contesting social and political control in Aceh. Dealing with the legislation of the controversial stipulation of rajam (stoning to death) in the local qanun of jinayat (Islamic penal law), this chapter explains how recent political changes have redirected the trajectory of the Islamisation of law in Aceh towards stagnation. Furthermore, by describing the tension between the executive and legislative branches of the Aceh government concerning this issue, the chapter demonstrates how various (in)formal sources of law (such as historical legal fact, Islamic legal jurisprudence, international human rights conventions and the Indonesian national constitution) are invoked and are highly contested.

Chapter 6 concerns various guidelines for land dispute settlement and asks to what extent Islam plays a role in this. As Muslims constitute the majority population and because Islamic sharia has been officially implemented in Aceh, a very crucial issue in this regard is whether religion plays a role in land disputes and how much disputants draw on religious reasoning? This chapter presents a case examined at the Jantho civil court concerning disputed land claims to argue that Islam's role appears to be that of marginal rhetoric and that 'discourse shopping' is evident among disputants. This chapter therefore illustrates how widespread legal pluralism has become.

Part Three addresses norms and practices contested between Aceh's villages and courtrooms. In particular, it deals with legal cases on property ownership, inheritance, insurance benefits, remarriage and divorce. Chapter 7 investigates whether orphaned grandchildren may replace their predeceased parent(s) as the 
substitute heirs. This chapter demonstrates how differences between the living Muslim law and the state's compilation of Islamic law often involve diverse legal reasoning and interpretations that come from different sources of law and are introduced by various agencies, including international NGOs.

Drawing on the decisions of sharia courts in Aceh and appellate courts at both provincial and national levels, Chapter 8 seeks to discover why insurance benefits are or are not considered a part of a bequest. This chapter identifies the norms that are often referred to and contested in the courts, and also reveals how different legal norms may exist parallel to, and in competition with, each other. Above all, this chapter highlights the legal paradoxes of the implementation of sharia in post-tsunami Aceh. Ironically, many judges of sharia courts rely on secular-national jurisprudence rather than giving priority to a local norm considered more in line with Islamic jurisprudence.

Chapter 9 focuses on the legality or validity of (re)marriage. It sheds light on a variety of legal norms and practices involved in saving a marriage after triple talaq (divorce) among the people of Aceh. Studies of modes of divorce pronouncement and its ensuing legal implications have received little scholarly attention. ${ }^{14}$ Although there are some studies on triple divorce in Islam (Mahmood I992; Al-Azri 20I I), an ethnographic study on the subject in question is truly rare, let alone one that employs a legal pluralist framework. By comparing court adjudications and village practices concerning marriage and divorce, this chapter discovers diverse ways of reconciling divorced couples, and inconsistent legal reasoning for keeping marriages in place. This chapter not only explores how legal scholars and jurists from diverse backgrounds perceive this problem, but also answers the questions: whose decision is legitimate?; is state legality considered subordinate to religious validity or vice versa?; would social acceptance of villagers, concerning a decision made either by the state or by religious authorities, be taken into account in determining its legality or legitimacy?

\section{Notes}

I. For further details on the Aceh conflict, see Kell (1995); Reid (2006); Miller (2009); Aspinall (2009a).

2. The proponents of sharia in Aceh consider the caning penalty as a kind of law of God. As it is mentioned in the Qur'an a couple of times, this penalty is believed to be an authentic punishment of Islam. On the contrary, the penalty of imprisonment is not only regarded as a man-made law, but is also seen as a Western secular product. By enforcing caning as one of the applicable punishments in Aceh, the proponents of sharia could claim to have legitimately implemented sharia in this region in a real sense.

3. For more on this particular issue, see Idria (2010); Wierienga (2010). 
4. Interview with Hamid Sarong, I 4 June 2005; interview with Safir Wijaya, I 7 June 2005.

5. See Articles 96-99 of Law i I of 2006.

6. See sharia-related provisions in this law, such as on the application of Islamic sharia (Articles I25-I27), the sharia court (Articles I28-137), the MPU or ulama council (Articles I38-I40), the Police Force (Article 207(I) and (4)), the Public Prosecutor (Articles 208(2) and 2 Io) and Human Rights (Article 227(IC)).

7. See Articles 69(c) and 70(c) of Law i I of 2006.

8. See, for instance, Ismuha ( 1978, I980); Sarong (2002); Bowen (2003); Muhammad (2003); Syahrizal (2003, 2004); Abubakar (2004, 2008); Hadi (2004); Ichwan (2007); Lindsey et al. (2007); Lindsey (2012); Feener (2013).

9. This information is available online at http://aceh.bps.go.id/? $r=$ data/dinamis\&id= 3 \&id $_{2}=\mathrm{I}_{4}$, accessed 7 April $20 \mathrm{I}_{4}$.

Iо. For more discussions on the arrival of Islam in Aceh and other islands of Indonesia in general, see Ricklefs (2001); Azra (2006).

I I. For more studies on Acehnese ulama, see Baihaqi (1983); Ismuha (I983); Alfian (1985); Saby (2001); Amiruddin (2004).

I2. Interview with Rafiuddin, the former chief of Jantho district Syar'iyah Court, 27 April 2006.

I3. For instance, Moors (I 995); Bowen (I 998b, 2003); Hirsch (I998); Tucker ( I998); Peletz (2002).

I4. Numerous works pay attention to historical as well as legal perspectives of divorce in Islam (Amira El Azhary 1996; Sonbol 1996; Ahmad 2003; Rapoport 2005; Omar 2007). Other works pay particular attention to divorce case studies at courts in different places and at different times (Layish I991; Shaham I994; Stiles 2003). In addition, there are several authors who examine formal mechanisms and types of procedures required for a valid divorce in different Muslim contexts (Carroll and Kapoor 1996; Carroll 1997; Bowen 2003; Kusrin 2006; Nakamura 2006; Cammack et al. 2007). 